\title{
MICROBIAL DEGRADATION OF POLYLACTIC ACID BIOPLASTIC
}

\author{
NOR HAFIZAH AHMAD KAMARUDIN ${ }^{1,2 *}$, NOOR DINA MUHD NOOR ${ }^{2,3}$ AND RAJA NOOR \\ ZALIHA RAJA ABD. RAHMAN ${ }^{2,4}$
}

${ }^{I}$ Centre of Foundation Studies for Agricultural Science, Universiti Putra Malaysia, 43400 Serdang Selangor, Malaysia. ${ }^{2}$ Enzyme and Microbial Technology Research Centre, Faculty of Biotechnology and Biomolecular Sciences, Universiti Putra Malaysia, 43400 Serdang Selangor, Malaysia. ${ }^{3}$ Department of Biochemistry, Faculty of Biotechnology and Biomolecular Sciences, Universiti Putra Malaysia, 43400 Serdang, Selangor, Malaysia. ${ }^{4}$ Department of Microbiology, Faculty of Biotechnology and Biomolecular Sciences, Universiti Putra Malaysia, 43400 Serdang, Selangor, Malaysia.

*Corresponding author: hafizah_kamar@upm.edu.my

Submitted final draft: 28 July 2020 Accepted:25 December $2020 \quad$ http://doi.org/10.46754/jssm.2021.10.021

\begin{abstract}
In modern urban society, plastic has become a major component in many applications. Despite their usefulness, plastics are known for their alarming resistance to biodegradation and therefore pose a huge burden on the environment. The surge in plastic waste has led to the development of biodegradable plastics. Biodegradable plastics are perceived to be one of the sustainable ways to reduce plastic wastes. Among the biodegradable plastics, polylactic acid (PLA), a bio-based plastic, has been widely used for diverse applications. PLA however, is known to be less susceptible to biodegradation and requires longer time to degrade in the natural environment compared to other aliphatic polyesters. Therefore, identification of PLA-degraders is the current focus of research. Potential PLA-degraders have been isolated from various sources, but the number is still limited. Considering temperature as one of the important factors in biodegradation, in this review, we categorize PLA degraders into three groups; thermophilic, mesophilic and psychrophilic, and discuss their relevance to PLA biodegradation. Enzymes associated with PLA degradation are described according to their temperature preference. One of the current limitations is the structural insights into the catalytic mechanism. Discovery of more PLA-degraders and understanding of the mechanism could aid in designing strategies to accelerate the biodegradation process.
\end{abstract}

Keywords: Biodegradable plastics, sustainability, polylactic acid, biodegradation, PLAdegraders.

\section{Introduction}

Accumulation of plastic waste is a current global concern that requires instant and continuous action from various sectors. Although plastics are useful in daily life due to their attractive characteristics such as high durability, tensile strength and flexibility, the growing demand for plastics by various industries makes it difficult to resolve the issue over poor recycling and improper waste management. The food and beverage sector is one of the fast-emerging sectors that is accelerating demand for plastics due to the rising popularity of packaged products. Takeout containers, microwaveable food trays, tableware and soft drink bottles are some of the products heavily consumed in the market. In addition, the unprecedented COVID-19 pandemic has inadvertently contributed to the increase in plastic wastes due to the rising use of food takeaways and goods deliveries that are plastic packaging-heavy during and even after the movement restrictions imposed by many countries.

Worldwide, plastics in the market are dominated by synthetic-based polymers, mainly petroleum hydrocarbons. Many plastics such as polyethylene (PET), polystyrene (PS), polypropylene (PP), polyethylene terephthalate (PET), and poly vinyl chloride (PVC) have been used in many industrial sectors not only for flexible and rigid packaging but also in building and construction, electrical and electronic products, and housewares. Despite their usefulness, these petroleum-based plastics are known to be resilient to degradation. Their persistence in the environment at the same 
state or small fragments (microplastics) for long periods of time poses a serious burden and adverse impact on the environment by harming organisms in various terrestrial and aquatic habitats (Sun et al., 2018; Jiang et al., 2019; Lahive et al., 2019), altering the natural biological and chemical processes and putting the food webs at risk of toxin introduction (Kale et al., 2015). Current treatments for plastic wastes include disposal in landfills, incineration, and chemical treatment and recycling (Gan \& Zhang 2019; Moharir \& Kumar, 2019). Disposal of plastic waste in landfills and incineration is associated with high energy consumption and generation of secondary pollutants (Webb et al., 2013; Moharir \& Kumar, 2019) while recycling is seen to be inefficient and compromising the quality of the polymer. Recent studies are more dedicated to finding solutions to treat plastic waste in a sustainable manner.

One of the promising ways to solve the plastic problem that is plaguing the environment is to consider alternative plastics having these two characteristics; 1) are derived from sustainable materials; 2) can be naturally degraded. On this premise, biodegradable plastics and bioplastics are introduced to the market. Besides Europe, bioplastics have captured the plastic market in Asia-Pacific countries, like China, India, South Korea and Japan, where the demand is steadily increasing, with $80 \%$ derived from the packaging industry (Source: Mordor Intelligence). In Malaysia, campaigns and policies to discourage single-use plastics have been implemented, and development of biodegradable plastics has started to grow. Malaysia aims to achieve zero single-use plastics for a cleaner and healthier environment by 2030. Current production of bioplastics in Malaysia is driven by the abundance of agricultural by-products such as palm oil waste and non-food crops that serve as renewable feedstocks.

Taken into account the current state of biodegradable plastics and mode of decomposition by biological treatment, this review focuses on the role of microbes specifically bacteria and their enzymes in degrading one of the most popular and promising biodegradable plastic, poly (L-lactic acid) (PLA). We highlight the diversity of PLAdegraders in terms of temperature preference and adaptation (thermophilic, mesophilic and psychrophilic) to provide useful information on the relevance of each bacterial category for isolation and identification of more PLA degraders and PLA depolymerases. At the end of the review section, we include some current understanding on PLA hydrolysis mechanism to shed light on the knowledge at molecular level and increase understanding of enzymatic degradation.

\section{Biodegradable Plastics}

Biodegradable plastics are compostable in the environment. Commonly used biodegradable plastics are poly (L-lactic acid) (PLA), poly (butylene succinate-co-adipate) (PBSA), poly (butylene succinate) (PBS) and polycaprolactone (PCL). PBS and PCL are grouped as biodegradable because they can be degraded by microorganisms although they are petroleum-based plastics. PHB and PLA, on the other hand, are synthesized from biologicalbased resources. These sustainable, eco-efficient products made up of renewable agricultural and biomass feedstock can attract markets and potentially outperform the petroleumbased products that are currently prevalent (Mohee et al., 2008). Bioplastics have attracted considerable interest due to their properties which are comparable to synthetic polymers and can potentially replace conventional synthetic plastics. Although the term 'biodegradable' has become appealing to the mass market and consumers, yet, in the natural environment, complete degradation will take years or decades, and potentially destructive small particles are generated in the process (Kubowicz \& Booth, 2017). Biodegradation involves a combined action of abiotic and biotic factors (Lucas et al., 2008; Sivan et al., 2011). Fragmentation of polymers into smaller pieces is suggested to be the starting process of degradation and the plastic is considered biodegradable only if it is 
consumed and metabolized by microorganisms in the subsequent process (Mohee et al., 2008). The action of exoezymes secreted by microorganisms is important to degrade the larger polymers before it can be incorporated into the microbial cells (Danso et al., 2019). In this review, we focus on PLA-type bioplastic because of its current wide usage in diverse applications.

\section{Poly(lactic) Acid Bioplastic}

Among the bioplastics, PLA presents the most promising biomass plastic with good mechanical properties and processability (Jem $\&$ Tan, 2020). PLA has the prerequisites of sustainability by being both biodegradable and bioplastic. The attractiveness of PLA in terms of its biocompatibility, high transparency, stiffness and thermoresistance (Elsawy et al., 2017) makes it useful for many purposes. PLA has been widely utilized as packaging films, containers, bottles with short shelf-life and single-used products (Jem \& Tan, 2020). Lactic acid, the monomer of PLA, is made from the fermentation of renewable sources, such as starch, corn and sugar. Lactic acid is a chiral molecule, existing as L- and D-lactic acid isomers. The production PLA from renewable sources is energy saving. PLA can also be chemically synthesized by ring-opening polymerization of lactide or directcondensation polymerization of lactic acid. Despite its interesting characteristics and great potential as a substitute for petroleum-based plastics, PLA has some limitations, including its biodegradability. The biodegradation of PLA has gained considerable attention because of its widespread use and disposal into the environment. Between the two stereoisomers of PLA; poly(L-lactic) PLLA and poly(Dlactic) PDLA, biodegradation of PLLA is more frequently reported compared to PDLA. In general, under typical composting facilities, PLA is degraded at high temperature $\left(>50^{\circ} \mathrm{C}\right)$ (Kawai et al., 2011) and requires months to be fully degraded. Due to this drawback, there is an urgent need for an efficient and eco-friendly method to degrade PLA.

\section{Microbial Degradation of Biodegradable Plastics}

The use of microorganisms is a promising solution to the plastic disposal issue and has been a focus of recent research. Intriguingly, the interactions between microorganisms, plastics and environmental factors may influence the environmental fate of terrestrial and marine plastics. In general, the entire decomposition of biodegradable plastics through bacterial and fungal activity occurs at slow rates (Muhonja et $a l ., 2018)$. The biodegradation rate is influenced by many factors including the molecular weight of the polymer (Tokiwa \& Calabia, 2004; Urbanek et al., 2020), the shape of the specimen, either in powder or film, (Yang et al., 2005) or particle size and surface area (Chinaglia et al., 2018). High molecular weight polymers are more recalcitrant to degradation and are very resistant to attack by enzymes (Danso et al., 2019). Natural degradation of polymers usually starts with the abiotic influence, such as photodegradation and thermo oxidative degradation followed by the action of microbes (Webb et al., 2013). These abiotic processes affect the chemical structure of the polymer chains. Apart from the properties of the polymer, degradation of biodegradable plastics is also determined by additives added to the final consumer products and the environment that they terminate. Nevertheless, because this biological method is a promising, potentially efficient, safer and more environmentally friendly approach than chemical and physical methods, such as landfill disposal and incineration, it is, therefore, important to discover more microorganisms that can degrade plastics, which can further be manipulated to increase the efficiency of biodegradation.

Microorganisms have developed many unique features that allow them to adapt to unfavourable conditions and evolve in contaminated environments. Microorganisms isolated from specific or extreme environments have shown many potentials for biotechnology applications and are often exploited for bioremediation and biodegradation processes. 
Based on the literature, plastic-degrading microbes have been extensively isolated from soil and compost compared to marine or aquatic environments. Also, it is worth noting that specific species may have the capability to degrade specific types of plastic or several types of polyesters. For example, Paenibacillus amylolyticus isolated from soil could degrade various types of polyesters including PLA, PBS, PBSA, PCL and PES and showed preference to degrade low-molecular weight polymers (Teeraphatpornchai et al., 2003). Yagi et al. (2014) identified unique eubacteria participating in anaerobic biodegradation of PCL and PLA at $37^{\circ} \mathrm{C}$ suggesting that some microbes are substrate specific.

In plastic-contaminated areas, biodegradable plastics are a source of carbon and energy (Chinaglia et al., 2018; Decorasi et al., 2019) likely when microbial nutrients are scant and limited. Under aerobic conditions, microorganisms assimilate the carbon chain of the brittle, small pieces plastics and mineralize it to carbon dioxide or use it to form the biomolecules (Zheng et al., 2005; Chinaglia et al., 2018). In general, degradation of polyesters by microorganisms has been suggested to involve mainly three sequential steps: 1) surface colonization or biofilm growth to physically break down the polyesters, 2) action of microbial exoenzymes to produce fragments of polyesters, and 3) assimilation of intermediates/molecules from the small fragments into bacterial metabolism (Mueller, 2006; Lucas et al., 2008).

\section{Degradation of Biodegradable Plastics by Extremophiles}

Extremophiles are one of the emerging sources of plastic-degrading microorganisms. There is a growing interest in extremophiles because of their ability to produce a wide array of useful exoenzymes (Di Donato et al., 2019). Extremophiles are characterized by their physical and chemical parameters that allow them to grow optimally. On the basis of temperature, extremophiles are divided into two main categories: thermophiles and psychrophiles. Thermophiles are microorganisms that can grow at temperatures above $60^{\circ} \mathrm{C}$, typically $60-80^{\circ} \mathrm{C}$, while hyperthermophiles are those that survive at temperatures above $80^{\circ} \mathrm{C}$. At elevated temperatures, thermophiles have high metabolism and produce enzymes that are highly stable (Haki \& Rakshit, 2003). It is well documented that thermophiles demonstrate substantial potential of degrading various kinds of environmental organic pollutants largely because at high temperature solubility and bioavailability of organic pollutants are enhanced (Margesin \& Schinner, 2001). Thermophiles have been widely reported in biodegradation of hydrocarbons such as petroleum hydrocarbons and currently perceived to be valuable in biodegradation of plastics, another carbonbased pollutant.

An increasing number of studies have found many potent extremophiles from various sources that have the ability to degrade plastics (Hadad et al., 2005; Michaud et al., 2007; Hanphakphoom et al., 2014, Shah et al., 2015; Dang et al., 2018). For example, Shah et al. (2005) isolated a bacterium identified as Ralstonia sp. MRT-TL from a hot spring that is capable of degrading $50 \%$ of PCL film within 10 days. The weight loss of the film is likely due to the breakdown of the long PCL chain into low molecular weight compounds. Çolak et al. (2005) reported a novel hot spring thermophile, Anoxybacillus gonensis G2A, that can decompose PHB film at $60^{\circ} \mathrm{C}$. The weight loss of $\mathrm{P}(3 \mathrm{HB})$ films was $6.9 \%, 13.4 \%$ and $24.0 \%$ observed at 24,48 and $72 \mathrm{~h}$, respectively. A novel thermophilic bacterial strain known as Bacillus sp. BCBT21 is capable of decomposing three different types of plastic bags - HL, VHL, and VN1 - with different chemical nature after 30 days (Dang et al., 2018).

Meanwhile, $70 \%$ of earth is covered by sea and serves as a reservoir of psychrophilic microorganisms at temperatures below $15^{\circ} \mathrm{C}$. Psychrotrophs (cold-tolerant) have a broader growth temperature range and are capable of growing optimally at temperatures 
above $15^{\circ} \mathrm{C}$ (Morita, 1975; Moyer \& Morita, 2007). Psychrophiles and psychrotrophs play an important role in the biodegradation of contaminants in cold environments, such as oceans, sea and polar regions. In contrast to high-temperature regions, contaminants may persist longer in cold environments because of the extreme condition and low bioavailability. In a marine environment, plastic waste accumulation, especially microplastics, has negatively impacted the ecosystem. But the information on biodegradation of plastics by aquatic microbes remains limited. A study conducted by Dussud et al. (2018) revealed that degradation of biodegradable polymers (artificially aged $\mathrm{OXO}$ and poly (3-hydroxybutyrate-co-3-hydroxyvalerate, PHBV) in an aquatic setting (aquariums with natural circulating seawater) was 30 times higher than that of non-degradable polymers. Members of Neptuniibacter sp., Phaeobacter sp., and Roseobacter sp. were dominantly found in the early colonization, growth and maturation phases, respectively. However, the role of each species needs to be further described.

Some of the microorganisms are also categorized as polyextremophiles, where they demonstrate the ability to survive at several extreme conditions. Piezophiles, microorganisms that can thrive in cold and high hydrostatic pressure in deep-sea environments, have also been reported capable of degrading aliphatic polyesters. In a study by Sekiguchi et al. (2010), four strains of piezophilic and piezotolerant bacteria (strains CT01, CT12, JT01 and JT04) isolated from deep-sea environments demonstrated high potential to degrade biodegradable PCL-type plastic. While many marine extremophiles are capable of producing enzymes with unique features (Di Donato et al., 2019) and could be of great interest to biotechnological applications, those reported to be involved in plastic degradation are relatively few and many are still unexplored. Therefore, it is apparent that much has to be done to identify potential plastic degrading bacteria in order to overcome the plastic waste problem and sustain both life on land and below water.

\section{PLA-degrading Bacteria}

Among all aliphatic polyesters, PLA is often associated with slow degradability due to low abundance of microbes that are able to decompose PLA in the environment (Tokiwa \& Calabia, 2004). Also, PLA decomposition is challenging because of its resistance to microbial attack under ambient settings (Farah et al., 2016). This poses an alarming threat as many countries are shifting to bioplastic usage. The slow degradation could lead to unnoticed accumulation of plastic waste, be it large or small fragments, before the degradation is complete.

Bacteria are known to be the key players in many biodegradation processes. Current research on PLA-degrading bacteria suggests that most PLA-degrading bacteria include members of Actinobacteria and predominantly belong to the Amycolatopsis genus (Butbunchu \& Pathom Aree, 2019). Because of their high occurrence as PLA-degraders, natural biodegradation of PLA is suggested to be influenced by the role of the members of this genus. In addition, members from the families of Bacillaceae, Pseudomonadaceae, Paenibacillaceae, Flavobacteriaceae, Xanthomonadaceae have also been reported (Table 1). Because PLA biodegradation is influenced by temperature, in the following section, we divide the PLAdegraders into three categories; thermophiles, mesophiles, and psychrophiles and discuss their relevance to PLA biodegradation. 
Table 1: Several thermophilic, mesophilic and psychrophilic bacteria capable of degrading PLA

\begin{tabular}{|c|c|c|c|c|c|}
\hline Category & Genus/Species & Source & $\begin{array}{c}\text { Optimal } \\
\text { Growth/ } \\
\text { Cultivation } \\
\text { Temperature } \\
\left({ }^{\circ} \mathrm{C}\right)\end{array}$ & $\begin{array}{l}\text { Type of } \\
\text { PLA/ } \\
\text { Form of } \\
\text { PLA }\end{array}$ & Reference \\
\hline \multirow[t]{5}{*}{ Thermophilic } & Bacillus smithii & $\begin{array}{l}\text { Garbage } \\
\text { fermentor }\end{array}$ & $\begin{array}{c}40-65 \\
\text { (optimal at 55) }\end{array}$ & PLLA & Sakai et al. (2001) \\
\hline & $\begin{array}{l}\text { Bacillus } \\
\text { stearothermophilus }\end{array}$ & Soil & 60 & PDLA & Tomita et al. (2003) \\
\hline & $\begin{array}{l}\text { Actinomadura sp. } \\
\text { strain T16-1 }\end{array}$ & $\begin{array}{c}\text { Thai forest } \\
\text { soil }\end{array}$ & 50 & PLA film & $\begin{array}{c}\text { Sukkhum et al. } \\
\text { (2009) }\end{array}$ \\
\hline & $\begin{array}{l}\text { Laceyella sacchari } \\
\text { strain LP175 }\end{array}$ & Forest soil & $50-55$ & PLLA & $\begin{array}{c}\text { Hanphakphoom et } \\
\text { al. (2014) }\end{array}$ \\
\hline & $\begin{array}{l}\text { Bacillus } \\
\text { licheniformis }\end{array}$ & Compost & 50 & PLA & $\begin{array}{c}\text { Prema \& Palempalli } \\
(2015)\end{array}$ \\
\hline \multirow[t]{9}{*}{ Mesophilic } & $\begin{array}{l}\text { Amycolatopsis sp. } \\
\text { strain K104-1 }\end{array}$ & Soil & 37 & $\begin{array}{l}\text { High MW } \\
\text { PLA } \\
\end{array}$ & $\begin{array}{c}\text { Nakamura et al. } \\
\text { (2001) }\end{array}$ \\
\hline & $\begin{array}{l}\text { Paenibacillus } \\
\text { amylolyticus strain } \\
\text { TB-13 }\end{array}$ & Soil & 30 & $\begin{array}{c}\text { PLA } \\
\text { emulsion }\end{array}$ & $\begin{array}{l}\text { Teeraphatpornchai } \\
\text { et al. }(2003)\end{array}$ \\
\hline & $\begin{array}{l}\text { Amycolatopsis } \\
\text { orientalis ssp. } \\
\text { orientalis }\end{array}$ & $\begin{array}{l}\text { Culture } \\
\text { collection }\end{array}$ & 30 & PLA film & Li et al. (2008) \\
\hline & $\begin{array}{l}\text { Amycolatopsis } \\
\text { thailandensis } \mathrm{sp} . \\
\text { nov. }\end{array}$ & Soil & $25-37$ & $\begin{array}{l}\text { PLA } \\
\text { emulsion }\end{array}$ & $\begin{array}{l}\text { Chomchoei et al. } \\
\text { (2011) }\end{array}$ \\
\hline & $\begin{array}{l}\text { Pseudomonas sp. } \\
\text { strain DS04-T }\end{array}$ & $\begin{array}{l}\text { Activated } \\
\text { sludge }\end{array}$ & 37 & PLLA & Wang et al. (2011) \\
\hline & $\begin{array}{l}\text { Aneurinibacillus } \\
\text { migulanus }\end{array}$ & Soil & $30-40.5$ & PLA film & Chaisu et al. (2012) \\
\hline & $\begin{array}{l}\text { Bacillus } \\
\text { amyloliquefaciens } \\
\text { MS2 }\end{array}$ & Compost & NR & PLA film & $\begin{array}{c}\text { Prema \& Palempalli } \\
\text { (2014) }\end{array}$ \\
\hline & $\begin{array}{l}\text { Pseudomonas sp. } \\
\text { MYK1 } \\
\text { Bacillus sp. MYK2 }\end{array}$ & $\begin{array}{l}\text { Digester } \\
\text { sludge }\end{array}$ & 30 & PLA & Kim et al. (2017) \\
\hline & $\begin{array}{l}\text { Chryseobacterium } \\
\text { sp. } \\
\text { Sphingobacterium } \\
\text { sp. } \\
\text { Pseudomonas } \\
\text { aeruginosa } \mathrm{S} 2 \\
\text { Pseudomonas } \\
\text { aeruginosa } \mathrm{S} 3\end{array}$ & Compost & 30 & PLA film & Satti et al. (2017) \\
\hline
\end{tabular}




\begin{tabular}{|c|c|c|c|c|c|}
\hline & $\begin{array}{l}\text { Stenotrophomonas } \\
\text { pavanii } \mathrm{CH} 1 \\
\text { Pseudomonas } \\
\text { geniculate WS3 }\end{array}$ & $\begin{array}{c}\text { Soil from } \\
\text { agricultural } \\
\text { areas, } \\
\text { sanitary } \\
\text { landfill sites } \\
\text { wastewater } \\
\text { sludges }\end{array}$ & $20-45$ & PLA & $\begin{array}{c}\text { Bubpachat et al. } \\
\text { (2018) }\end{array}$ \\
\hline & $\begin{array}{l}\text { Bacillus pumilus } \\
\text { (B12) }\end{array}$ & $\begin{array}{l}\text { Agricultural } \\
\text { soil }\end{array}$ & $21-37$ & $\begin{array}{l}\text { High } \\
\text { molecular } \\
\text { weight } \\
\text { PLA film }\end{array}$ & $\begin{array}{l}\text { Bonifer et al. } \\
\text { (2019) }\end{array}$ \\
\hline Psychrophilic & $\begin{array}{l}\text { Pseudomonas sp. } \\
\text { and } \\
\text { Rhodococcus sp. }\end{array}$ & Arctic soil & 28 & PLA & $\begin{array}{l}\text { Urbanek et al. } \\
\qquad(2017)\end{array}$ \\
\hline
\end{tabular}

Note: NR - Not Reported

\section{Thermophilic PLA-degrading Bacteria}

Thermophilic bacteria have been widely reported capable of degrading PLA compared to their mesophilic and psychrophilic counterparts. The focus of isolating thermophilic bacteria is based on the notion that natural degradation of PLA (PLLA) in landfills and recycling process by enzymatic method takes place at high temperature (Hanphakphoom et al., 2013). Besides, effective biodegradation of bioplastics was observed between $70 \%$ and $90 \%$ at a temperature range of $58-65^{\circ} \mathrm{C}$ (Rugerro et al., 2019). Most thermophilic PLA-degrading bacteria have been isolated from various sources including agricultural soil, garbage fermentor, forest soil, activated sludge and compost (Sakai et al., 2001; Prema \& Palempalli, 2015). A thermophilic PLA-degrading bacterium was isolated from a garbage fermentor which operated at $55-60^{\circ} \mathrm{C}$ by Sakai and co-workers (2001). This bacterial strain grew at $45-60^{\circ} \mathrm{C}$ and exhibited optimal growth temperature at $55^{\circ} \mathrm{C}$. However, under aerobic conditions at its optimal temperature, the growth was poor. A soil-isolate closely related to species Geobacillus thermocatenulatus was able to grow at $60^{\circ} \mathrm{C}$ on medium supplemented with $0.5 \%$ PLA film (Tomita et al., 2004). Sukkhum et al. (2009) used a clear zone method to isolate PLAdegrading actinomycetes from various forest soils at high temperature. Among the 13 isolates, strain T16-1 showed the largest clearing zone $(3.6 \mathrm{~cm})$ and highest PLA degradation activity (22 $\mathrm{U} / \mathrm{mL}$ ) in the liquid culture. The strain was identified as Actinomadura keratinilytica strain T16-1, a member of Thermomonosporaceae family. Meanwhile, Hanphakphoom et al. (2013) isolated eleven strains of thermophilic poly(Llactide)-degrading bacteria from forest soils that showed positive clearing zone on emulsified PLLA agar plate. Strain LP175 which was identified as Laceyella sacchari demonstrated the highest PLLA degradability at $50^{\circ} \mathrm{C}$ for 4 days. A thermophilic Bacillus licheniformis isolated from compost of a plastic rich environment showed a significant degradation of PLA at $50^{\circ} \mathrm{C}$ (Prema \& Palempalli, 2015).

\section{Mesophilic PLA-degrading Bacteria}

While thermophilic PLA-degrading bacteria are advantageous especially for biodegradation in composting facilities that usually operate at $40-70^{\circ} \mathrm{C}$, application of PLA-degraders that work at moderate and low temperatures can be economical in terms of energy consumption. Furthermore, biodegradation of PLA in nature, given the conditions in most settings, is mainly driven by the activity of mesophilic bacteria (Pattanasuttichonlakul et al., 2018). In this sense, mesophilic and psychrophilic bacteria capable of breaking down polyesters can provide more 
options to strategize efficient ways to rapidly decompose bioplastics in different environments. Soils from landfill, compost and agricultural lands, as well as wastewater sludges are sources of mesophilic PLA-degrading bacteria. A higher probability to obtain PLA-degrading bacteria is observed in soils exposed or contaminated with plastic wastes, such as sanitary landfill and wastewater sludges compared to agricultural soils (Bubpachat et al., 2018). A soil Actinomycetes identified as Amycolatopsis thailandensis sp. nov. (strain CMU-PLA07) was reported to be able to degrade PLA. The bacteria had optimal growth temperature at $25-37^{\circ} \mathrm{C}$ and no growth was observed at $45^{\circ} \mathrm{C}$ (Chamchoei et al., 2011). A-PLA degrading mesophile was isolated from compost and based on 16S rDNA sequence analysis, the species was identified as Bacillus amyloliquefaciens MS2 (Prema \& Palempalli, 2014). Satti et al. (2017) tested the capability of four isolates from compost to degrade PLA at $30^{\circ} \mathrm{C}$ by supplementing the culture with PLA as the sole carbon source. All four strains (Chryseobacterium sp. strain S1, Sphingobacterium sp. strain S2, and Pseudomonas aeruginosa strain S3 \& S4) demonstrated PLA degradation ability at ambient temperature. Bubpachat and coworkers (2018) reported two PLA-degrading bacteria isolated from soil and wastewater sludge in an attempt to search for new efficient mesophilic PLA-degrading strains. The two strains, Stenotrophomonas pavanii and Pseudomonas geniculate WS3 were able to grow at temperatures of $25-40^{\circ} \mathrm{C}$ and degrade PLA at $30^{\circ} \mathrm{C}$. Interestingly, $P$. geniculate WS3 demonstrated efficient degradation activity toward beverage cup PLA and PLA by more than $90 \%$ of weight loss in the non-sterilized soil mixture under thermophilic conditions for 12 days (Pattanasuttichonlakul et al., 2018). Decorasi et al. (2019) isolated four Actinomycete strains (designated as SO1.1, SO1.2, SNC, and SST) from soils of different geographical areas. All four strains were able to grow at temperatures below $45^{\circ} \mathrm{C}\left(28\right.$ and $\left.37^{\circ} \mathrm{C}\right)$ and thus are grouped as mesophiles. Strain SNC isolated from soil close to a city road showed the best degradative capabilities at $30^{\circ} \mathrm{C}$ by inducing $36 \%$ weight loss of PLA film in soil extract medium with $0.1 \%$ gelatin.

\section{Psychrophilic PLA-degrading Bacteria}

Since plastic wastes can be found in numerous parts of the Earth, including cold environments, it is likely that more polyestersdegrading microorganisms can be discovered. Psychrophilic microorganisms can be found in low temperature environments, including the deep sea, mountains and polar regions (D'Amico et al., 2006). Other sources include highaltitude mountains, glaciers or natural caves, while oceans provide the largest psychrophilic reservoir (Mergesen \& Feller, 2010). Although current studies on psychrophiles capable of degrading plastic are scarce, the potentials shown by this group of microorganisms should not be neglected. Psychrophiles may be employed for biodegradation in marine ecosystems, during winter in temperate regions or other cold ecosystems. Similar to its higher counterparts, the attractiveness of psychrophiles is due to their unique enzymes. Since a large amount of plastic debris has been entering the oceans for many decades and changing the indigenous ecosystem, marine bacteria have evolved the capability to colonize and interact with plastic surfaces. This interaction, which is influenced by many factors, such as substrate type, surrounding environment, geographical location and seasonal variation of environmental parameters causes the formation of biofilm (Kirstein et al., 2019).

Biodegradable plastics, such as PCL, PBSA and P3HB are proven biodegraded in the marine environment and the rate depends on the variety of organisms in the sea, and physical and chemical effects (Nakayama et al., 2019). In the same study, PLLA was found to be biodegraded at a very slow rate, even after 4 weeks of treatment using seawater. A study reported psychrophilic microorganisms displaying microbial activity towards PLA. Urbanek and co-workers (2017) isolated psychrophilic bacteria from Artic soil in an attempt to identify Arctic microorganisms with best biodegradability features. Out of 113 bacterial isolates, $45.13 \%$ of the bacteria grew 
on $0.1 \%$ emulsified PLA at $28^{\circ} \mathrm{C}$ after $2-3$ days during the initial screening, however PLA was the hardest to degrade compared to other tested polymers, PCL and PBSA. The resilience of PLA against degradation has been suggested to be related to the low humidity when cultured on PLA-emulsified plates (Urbanek et al., 2017).

\section{PLA Depolymerases}

The bio-based polymer is preferentially attacked by microorganisms. Since plastic is made up of polymer with high molecular weight, this polymer is unable to cross the cell membrane (Pattanasuttichonlakul et al., 2018). During the depolymerization process, microorganisms secrete extracellular enzymes that are responsible for breaking down complex polymeric structures to short monomers (Palmisano \& Pettigrew, 1992). Recent studies are focusing more on characterizing the PLA-degrading enzymes or known as PLA depolymerase. Hydrolases such as protease, lipase, esterase and cutinase are identified to play a chief role in the biodegradation of PLA. The fact that PLA is an aliphatic polyester means that the mechanism of degradation of PLA is primarily by the action of hydrolases on the ester bond (Li et al., 1994; Panyachanakul et al., 2019). According to Lenz (1993), there are two modes of hydrolytic cleavage: 1) exo-attack, where the hydrolysis takes place at the polymer chain terminus and results in small oligomers or monomers that can be incorporated into the cells, or 2) endo-attack, where hydrolysis occurs somewhere along the polymer chain and the products cannot be assimilated by the cells.

Among the PLA-degrading hydrolases, serine proteases or protease-like enzymes have been earlier reported to be associated with PLA degradation, where proteinase $\mathrm{K}$ was the first PLA-degrading enzyme reported (Williams, 1981). Esterase and lipase belong to the same family and both capable of degrading PLA but are distinguished by their substrate preference. Esterase acts on shorter chain fatty acid esters, thus targeting the low molecular weight PLA, whereas lipase preferentially hydrolyses high molecular weight PLA (Urbanek et al., 2020). Cutinase is an enzyme of mainly fungal origin and acts on cutin substrate. Cutinase and lipase share similar endo-type action in biodegradation of polyester by cleaving the ester bond between alcohol and carboxylic acid (Shi et al., 2020). Unlike lipase, cutinase hydrolyses esters with shorter chain length $(\mathrm{C}<10)$ and lacks interfacial activation, such as that observed in lipase family.

To date, most reported biodegradation of PLA involves poly (L-lactic acid) PLLA (Sukkhum et al., 2009; Chomchoei et al., 2011; Hanphakphoom et al., 2014) whereas reports on hydrolysis poly (D-lactic acid) PDLA by PLA depolymerase are very limited. In a study conducted by Kawai et al. (2011), on the hydrolytic activities of protease, lipase and PLA-degrading enzymes to different types of PLA; (poly (L-lactic acid) (PLLA) and poly (D-lactic acid), they concluded that protease activity is more specific to PLLA while lipase prefers PDLA as substrate.

\section{Thermostable PLA Depolymerases}

In many bio-based industrial processes, extremophilic enzymes offer many attractive improvements to reaction efficiency. Of these, thermophilic enzymes have long been considered as a valuable biocatalyst for hightemperature reactions primarily due to their robust stability and increased resistance to proteolysis at elevated temperatures. Enzymes are considered thermostable when they can function above $55^{\circ} \mathrm{C}$; usually in the range of 60 $80^{\circ} \mathrm{C}$ and can originate either from thermophilic or mesophilic microorganisms. At temperatures below $40^{\circ} \mathrm{C}$, the activity will typically diminish (Vieille \& Zeikus, 2001). The application of thermostable enzymes is seen not limited only to industrial processes, but they are also useful in bioremediation. Evidently, there has been a considerable interest in identification of novel thermostable PLA-degrading enzymes. Table 2 summarizes several thermostable bacterial PLA-depolymerases that have been reported. A purified extracellular fibrinolytic serine protease is able to degrade PLA at temperatures 
of $55-60^{\circ} \mathrm{C}$. This $24-\mathrm{kDa}$ protein hydrolyses high molecular weight PLA and the maximum degradation was observed at pH 9.5 (Nakamura et al., 2001). A crude wild-type esterase from Bacillus smithii works optimally at $60^{\circ} \mathrm{C}$ on PLA and other fatty acid esters (Sakai et al., 2001). Akutsu-Shigeno et al. (2003) purified and characterized a recombinant PLA depolymerase which functions at $45-55^{\circ} \mathrm{C}$. This alkaline depolymerase is capable of decomposing a variety of biodegradable polyesters including PLA. PLA with lower molecular weight showed high degradability. Besides PLA, this enzyme could hydrolyse triolein and tributyrin and various p-nitrophenyl alkyl esters, especially butyl ester. Three thermostable PLAases (PLAase I, II, and III) was reported by Li et al. (2008). The enzymes originating from Amycolatopsis orientalis ssp. orientalis hydrolysed PLA and casein, but the activity was inhibited by aprotinin. A thermostable serine protease was identified from Actinomadura sp. strain T16-1. Hydrolysis of PLA was optimum at $70^{\circ} \mathrm{C}$ (Sukkhum et al., 2009).

Meanwhile, Prema \& Palempalli (2015) described a PLA depolymerase from Bacillus licheniformis that is active at $50-60^{\circ} \mathrm{C}$. Apart from PLA, the hydrolytic activity was observed in the presence of gelatin and casein as substrates. A PLA depolymerase from Pseudomonas tamsuii TKU015 exhibited optimum activity at $60^{\circ} \mathrm{C}$ and retained its activity by $50 \%$ at $80^{\circ} \mathrm{C}$. It is worth mentioning that the bacterial strain was identified as a mesophilic Pseudomonas. Hydrolytic activity determination suggested that lipase and protease activity were not present. This enzyme could represent a novel PLA depolymerase that acts on the ester bond between lactate units but not on some common lipase and protease substrates (Liang et al., 2016).

\section{Mesostable and Cold Active/Adapted PLA Depolymerases}

In contrast to thermostable enzymes, mesophilic (mesostable) and psychrophilic (cold active/ adapted) enzymes usually work best at temperature ranges of 25 to $50^{\circ} \mathrm{C}$ and 5 to $25^{\circ} \mathrm{C}$, respectively (Vieille \& Zeikus, 2001). Several mesophilic and psychrophilic PLA depolymerases have been reported (Table 3). A PLA depolymerase which identified as elastaselike protease was reported from Amycolatopsis sp. strain K104-1. The purified enzyme obtained from extracellular fraction consists of 238 amino and the mature enzyme encodes for a protein with a size of 20,904 Da. Although the optimal temperature was not specifically mentioned, degradation test using PLA emulsion was conducted at $37^{\circ} \mathrm{C}$. A decrease in emulsion turbidity was recorded within 3 to 6 hours and complete disappearance of PLA spot (measured by thin layer chromatography) was observed after 6 hours (Matsuda et al., 2005). Bubpachat and co-workers (2018) isolated two mesophilic bacteria producing protease and PLA-degrading enzymes that hydrolyse PLA at $30^{\circ} \mathrm{C}$. Stenotrophomonas pavanii $\mathrm{CH} 1$ produced a protease that has optimal $\mathrm{pH}$ of 7.0-7.5. Pseudomonas geniculata WS3 produced the highest levels of PLA-degrading enzyme at $\mathrm{pH}$ 8.0. Recently, an esterase from Pseudomonas aeruginosa strain S3 capable of depolymerizing PLA films was purified with a molecular mass of approximately $34 \mathrm{kDa}$. This enzyme was stable at wide temperature and $\mathrm{pH}$ ranges, with highest stability at $30^{\circ} \mathrm{C}$ and pH 7.0 (Noor et al., 2020).

Structural flexibility of enzymes from psychrophilic organisms allows them to exhibit 10 times higher activity at low and moderate temperatures compared to their mesophilic homologues (Morgesin \& Feller, 2010; Cavicchioli et al., 2011), thus, enzymes from psychrophiles can efficiently break down PLA at cold temperatures. To date, there is little information on cold-active/adapted PLAdepolymerases. One of the few psychrophilic PLA-degrading enzymes reported is ABO2449 from Alcanivorax borkumensis. This enzyme is suggested to be a cold-adapted esterase by its ability to retain $32 \%$ of its maximal activity at $5^{\circ} \mathrm{C}$ and hydrolyses soluble naphthyl- and nitrophenyl-esters of C2-C4. Furthermore, the cold-adapted property was confirmed by its low thermostability $\left(\mathrm{T}_{\text {agg }}=32.3 \pm 0.5^{\circ} \mathrm{C}\right)$ 
Table 2: Several reported thermostable bacterial PLA-depolymerases/PLA-degrading enzymes

\begin{tabular}{|c|c|c|c|c|c|c|}
\hline Enzyme & Fraction & $\begin{array}{c}\text { Molecular } \\
\text { Weight } \\
\text { (kDa) }\end{array}$ & $\begin{array}{c}\text { Optimum } \\
\text { Temperature } \\
\left({ }^{\circ} \mathrm{C}\right)\end{array}$ & $\begin{array}{c}\text { Optimum } \\
\text { pH }\end{array}$ & $\begin{array}{l}\text { Substrate/ } \\
\text { Inhibitor }\end{array}$ & Reference \\
\hline $\begin{array}{l}\text { Serine } \\
\text { protease }\end{array}$ & $\begin{array}{l}\text { Purified } \\
\text { wild-type } \\
\text { (culture } \\
\text { supernatant) }\end{array}$ & 24.0 & $55-60$ & 9.5 & High MW PLA & $\begin{array}{c}\text { Nakamura } \\
\text { et al. } \\
\text { (2001) }\end{array}$ \\
\hline $\begin{array}{l}\text { Serine } \\
\text { protease }\end{array}$ & $\begin{array}{l}\text { Purified } \\
\text { wild-type } \\
\text { (culture } \\
\text { supernatant) }\end{array}$ & 30.0 & 70 & 10.0 & $\begin{array}{c}\text { PLA, Gelatin, } \\
\text { Suc-(Ala)3-pNA } \\
\text { Inhibited by } \\
\text { EDTA, PMSF } \\
\text { and diisopropyl } \\
\text { fluorophophates }\end{array}$ & $\begin{array}{l}\text { Sukkhum } \\
\text { et al. } \\
\text { (2009) }\end{array}$ \\
\hline $\begin{array}{l}\text { PLLA } \\
\text { degrading } \\
\text { enzyme } \\
\text { (esterase) }\end{array}$ & $\begin{array}{l}\text { Purified } \\
\text { wild-type } \\
\text { (culture } \\
\text { supernatant) }\end{array}$ & 62.5 & 60 & 5 & $\begin{array}{l}\text { PLLA and fatty } \\
\text { acids esters }\end{array}$ & $\begin{array}{l}\text { Sakai et al. } \\
\text { (2001) }\end{array}$ \\
\hline $\begin{array}{l}\text { PLA } \\
\text { depolymerase }\end{array}$ & $\begin{array}{l}\text { Purified } \\
\text { recombinant }\end{array}$ & 22.0 & $45-55$ & 10 & $\begin{array}{c}\text { PLA, PBS, } \\
\text { PBSA, PCL, } \\
\text { PES, Tributyrin, } \\
\text { Triolein }\end{array}$ & $\begin{array}{l}\text { Akutsu- } \\
\text { Shigeno et } \\
\text { al. (2003) }\end{array}$ \\
\hline $\begin{array}{l}\text { PLAase I } \\
\text { PLAase II } \\
\text { PLAase III }\end{array}$ & $\begin{array}{l}\text { Purified } \\
\text { wild-type } \\
\text { (culture } \\
\text { supernatant) }\end{array}$ & $\begin{array}{l}24.0 \\
19.5 \\
18.0\end{array}$ & $\begin{array}{l}60 \\
50 \\
60\end{array}$ & $\begin{array}{c}9.5 \\
10.5 \\
9.5\end{array}$ & $\begin{array}{l}\text { PLA, casein } \\
\text { Inhibited by } \\
\text { aprotinin and } \\
\text { PMSF (PLAse } \\
\text { activity) }\end{array}$ & $\begin{array}{l}\text { Li et al. } \\
(2008)\end{array}$ \\
\hline $\begin{array}{l}\text { PLA } \\
\text { depolymerase }\end{array}$ & $\begin{array}{l}\text { Purified } \\
\text { wild-type } \\
\text { (culture } \\
\text { supernatant) }\end{array}$ & 34.0 & 50 & 8.5 & $\begin{array}{l}\text { PLA, triolein, } \\
\text { poly(b- } \\
\text { hydroxybutyrate), } \\
\text { and poly(e- } \\
\text { caprolactone })\end{array}$ & $\begin{array}{l}\text { Wang et al. } \\
\text { (2011) }\end{array}$ \\
\hline $\begin{array}{l}\text { PLLA } \\
\text { degrading } \\
\text { enzyme } \\
\text { (serine } \\
\text { protease) }\end{array}$ & $\begin{array}{l}\text { Purified } \\
\text { wild-type } \\
\text { (culture } \\
\text { supernatant) }\end{array}$ & 28.0 & 60 & 9 & $\begin{array}{l}\text { PLLA, casein and } \\
\text { gelatin }\end{array}$ & $\begin{array}{l}\text { Hanphak- } \\
\text { phoom et } \\
\text { al. (2014) }\end{array}$ \\
\hline $\begin{array}{l}\text { PLA } \\
\text { depolymerase }\end{array}$ & $\begin{array}{l}\text { Purified } \\
\text { wild-type } \\
\text { (culture } \\
\text { supernatant) }\end{array}$ & 44.0 & $50-60$ & $6-7$ & $\begin{array}{l}\text { PLA, casein, } \\
\text { gelatin }\end{array}$ & $\begin{array}{c}\text { Prema \& } \\
\text { Palempalli } \\
(2015)\end{array}$ \\
\hline $\begin{array}{l}\text { PLA } \\
\text { depolymerase }\end{array}$ & $\begin{array}{l}\text { Purified } \\
\text { wild-type } \\
\text { (culture } \\
\text { supernatant) }\end{array}$ & 58.0 & 60 & 10 & $\begin{array}{l}\text { PLA, Fibrinogen, } \\
\text { tributyrin }\end{array}$ & $\begin{array}{l}\text { Liang et al. } \\
\text { (2016) }\end{array}$ \\
\hline $\begin{array}{l}\text { PLA } \\
\text { degrading } \\
\text { enzyme }\end{array}$ & $\begin{array}{l}\text { Crude wild- } \\
\text { type }\end{array}$ & 30.0 & 60 & 8 & PLA & $\begin{array}{c}\text { Panya- } \\
\text { chanakul et } \\
\text { al. (2019) }\end{array}$ \\
\hline
\end{tabular}

Note: NR - Not Reported 
Table 3: Several reported mesostable and cold-adapted bacterial PLA depolymerases/PLA-degrading enzymes (including PLA depolymerases tested at moderate temperature)

\begin{tabular}{|c|c|c|c|c|c|c|}
\hline Enzyme & Fraction & $\begin{array}{c}\text { Molecular } \\
\text { Weight } \\
\text { (kDa) }\end{array}$ & $\begin{array}{c}\text { Optimum/ } \\
\text { Tested } \\
\text { Temperature } \\
\left({ }^{\circ} \mathrm{C}\right)\end{array}$ & $\begin{array}{c}\text { Optimum } \\
\text { pH }\end{array}$ & Substrate & Reference \\
\hline Esterase & $\begin{array}{l}\text { Purified } \\
\text { recombinant }\end{array}$ & 29.8 & $\begin{array}{c}37^{\circ} \mathrm{C} \text { for PLA } \\
\text { hydrolysis }\end{array}$ & NR & $\begin{array}{l}\text { PLA and } \\
\text { PET }\end{array}$ & $\begin{array}{l}\text { Ribitsch et al. } \\
\quad \text { (2012) }\end{array}$ \\
\hline $\begin{array}{l}\text { Esterase } \\
\mathrm{ABO} 2449\end{array}$ & $\begin{array}{l}\text { Purified } \\
\text { recombinant }\end{array}$ & NR & $\begin{array}{c}30-37 \\
\text { (retain } 32 \% \text { of } \\
\text { its maximal } \\
\text { activity at } 5 \\
{ }^{\circ} \mathrm{C} \text { ) }\end{array}$ & $\mathrm{pH} 9.5-10$ & $\begin{array}{l}\text { PLA, } \\
\text { Monoester } \\
\text { substrates, } \\
\text { tributyrin } \\
\text { (C4) }\end{array}$ & $\begin{array}{c}\text { Hajighasemi et } \\
\text { al. (2016) }\end{array}$ \\
\hline Esterase & $\begin{array}{l}\text { Purified } \\
\text { wild-type }\end{array}$ & 34 & 30 & pH 7 & PLA film & $\begin{array}{l}\text { Noor } \text { et al. } \\
\quad(2020)\end{array}$ \\
\hline $\begin{array}{l}\text { PLA } \\
\text { depolymerase } \\
\text { (serine } \\
\text { protease) }\end{array}$ & $\begin{array}{l}\text { Purified } \\
\text { wild-type } \\
\text { (culture } \\
\text { supernatant) }\end{array}$ & 72.5 & $\begin{array}{c}\mathrm{NR} \\
\text { (Tested at } 37 \\
\left.{ }^{\circ} \mathrm{C}\right)\end{array}$ & NR & $\begin{array}{l}\text { PLA, } \\
\text { casein, } \\
\text { gelatin }\end{array}$ & $\begin{array}{c}\text { Prema \& } \\
\text { Palempalli } \\
(2014)\end{array}$ \\
\hline $\begin{array}{l}\text { PLA } \\
\text { depolymerase } \\
\text { (elastase-like } \\
\text { protease) }\end{array}$ & $\begin{array}{l}\text { Purified } \\
\text { recombinant } \\
\text { (culture } \\
\text { supernatant) }\end{array}$ & $\begin{array}{c}24.2 \\
\text { (mature } \\
20.9)\end{array}$ & 37 & NR & PLA & $\begin{array}{l}\text { Matsuda et al. } \\
\quad(2005)\end{array}$ \\
\hline $\begin{array}{l}\text { Protease } \\
\& \text { PLA } \\
\text { degrading } \\
\text { enzyme }\end{array}$ & $\begin{array}{l}\text { Crude wild- } \\
\text { type }\end{array}$ & NR & $\begin{array}{c}\mathrm{NR} \\
\left(\begin{array}{c}\text { Tested at } 30 \\
\left.{ }^{\circ} \mathrm{C}\right)\end{array}\right.\end{array}$ & $\begin{array}{c}\mathrm{pH} 7.5-\mathrm{pH} \\
8.0\end{array}$ & $\begin{array}{l}\text { PLA \& } \\
\text { gelatin }\end{array}$ & $\begin{array}{l}\text { Bubpachat et } \\
\text { al. (2018) }\end{array}$ \\
\hline
\end{tabular}

Note: NR - Not Reported

and the ability of the bacteria to grow at $4^{\circ} \mathrm{C}$ (Hajighasemi et al., 2016).

Although PLA degrading enzymes acting at moderate and low temperature have been reported, the efficiency of biodegradation is accompanied by some limitations. Studies have shown that biodegradation of PLA in mesophilic conditions is slower compared to thermophilic conditions. The change in the molecular weight of the polymer occurs at a slow rate in both aerobic and anaerobic settings, likely due to the lack of capability to hydrolyse the high molecular weight polyesters, such as PLA and PCL (Yagi et al., 2014; Bubpachat et al., 2018). According to a study by Ribitsch et al. (2012) the polymer chain must be flexible to provide higher accessibility for enzymatic attack and hydrolysis, thus, reactions at high temperatures are favourable. Nevertheless, PLA degradation in mesophilic conditions is deemed to be important as it represents the natural degradation in most environments.

\section{Current Understanding on PLA Depolymerase Structure and Mechanism}

In general, the literature suggests that PLA depolymerase falls in the group of hydrolases. Therefore, structural investigations are important to unveil the mechanism of PLA hydrolysis by PLA depolymerases. Identification of the active site and key residues involved in the catalysis may assist in the design and manipulation of the enzyme to overcome the limitations of enzyme-mediated PLA degradation. Several 
studies have examined and analysed the amino acid sequences and functional roles of specific residues in bacterial PLA depolymerases.

Lipase, esterase and cutinase share the canonical $\alpha / \beta$ hydrolase fold with Ser-His-Asp as the catalytic triad. Meanwhile, protease, specifically serine protease, has been reported to be involve in the hydrolysis of polyesters (Lim et al., 2005). The presence of serine, which acts as a nucleophile, is critical to drive the hydrolytic reaction. Hydrolytic mechanism by serine protease occurs in two-sequential steps, acylation and deacylation (Hedstrom, 2002). In general, the reaction begins when the hydroxyl group of a serine residue attacks the substrate scissile bond forming the first tetrahedral intermediate, acyl enzyme and releasing the first product. A second intermediate is formed when a water molecule attacks the acyl enzyme and the second product is released.

The gene encoding PLA depolymerase from Paenibacillus amylolyticus strain TB-13 was cloned and over-expressed in Escherichia coli. The recombinant lipase-type PLA depolymerase displayed a conserved pentapeptide Ala-HisSer-Met-Gly such as that present in Bacillus lipase (Akutsu-Shigeno et al., 2003). Similarly, the presence of serine residue in the catalytic site of PLA depolymerase from Bacillus amyloliquefaciens MS2 was confirmed by a complete inhibition when treated with serine inhibitors, phenylmethylsulfonylfluoride and aprotinin (Prema \& Palempalli, 2015).

Matsuda et al. (2005) suggested that the depolymerization of PLA by an elastaselike PLA depolymerase follows the catalytic mechanism of the chymotrypsin family. Based on sequence analysis, residues H74, D111, and S197 are proposed to be the catalytic triad of the elastase-like PLA depolymerase. The oxygen of nucleophilic Ser195 (chymotrypsin numbering) attacks the peptide bond or ester bond and generates an acyl intermediate and deliberates the first product. Subsequently during the deacylation step, covalent intermediate is hydrolysed and active enzymes are regenerated when the second product is released.
An extensive screening of 90 purified microbial $\alpha / \beta$ hydrolases by Hajighasemi et al. (2016) led to the identification of two uncharacterized proteins ABO2449 from Alcanivorax borkumensis and RPA1511 from Rhodopseudomonas palustris that are able to completely hydrolyse solid PLA. The crystal structure of RPA1511 revealed that the catalytic triad consists of Ser114, Asp242 and His270. The catalytic Ser114 and several hydrophobic residues, including Ile245 and Val249, forms the substrate acyl-binding pocket of RPA1511. The mechanism was proposed based on classic Ser hydrolase catalysis comprising acylation and deacylation steps. Several residues (Gln172, Leu212, Met215, Trp218, and Leu220) were also identified to be the key in PLA hydrolysis by RPA1511.

\section{Future Perspective and Challenges}

PLA is a promising sustainable material that potentially serves as a substitute for petroleumbased plastics. The emergence of PLA in the market raises the issues related to its slow degradability. The current challenge is to improve the biodegradation rate in order to avoid problems related to plastic pollution from worsening. Microorganisms are known as the key players in polymer biodegradation, however the diversity of PLA-degrading bacteria and known PLA depolymerases are still rather limited. Although the number of reports is increasing, the importance and limitation of different groups of bacteria has not been extensively discussed. The review summarizes the current status and gaps in PLA biodegradation, especially in exploration of PLA degraders and their relevant enzymes. Given different environments and conditions, thermophilic, mesophilic and psychrophilic bacteria are important for biodegradation at various settings. Also, it is evidenced that several thermostable PLA-degrading enzymes are produced by mesophilic bacteria. In addition, further studies need to be directed to understanding the biodegradation mechanism at molecular level to allow engineering of PLAdepolymerases with robust activity and broad 
substrate specificity. Other aspects that could be described include the complex interactions between enzymatic degradation and factors that could accelerate the biodegradation of PLA in both laboratory setup and natural environment.

\section{Acknowledgements}

The authors would like to thank Universiti Putra Malaysia for the research opportunity and reviewers for constructive comments on the manuscript.

\section{References}

Akutsu-Shigeno, Y., Teeraphatpornchai, T., Teamtisong, K., Nomura, N., Uchiyama, H., Nakahara, T., \& Nakajima-kambe, T. (2003). Cloning and sequencing of a poly(DL-Lactic Acid) depolymerase gene from Paenibacillus amylolyticus Strain TB-13 and its functional expression in Escherichia coli. Applied and Environmental Microbiology, 69(5), 2498-2504. https://doi.org/10.1128/AEM. 69.5.2498

Bonifer, K. S., Wen, X., Hasim, S., Phillips, E. K., Dunlap, R. N., Gann, E. R., DeBruyn, J. M., \& Reynolds, T. B. (2019). Bacillus pumilus B12 degrades polylactic acid and degradation is affected by changing nutrient conditions. Frontiers in Microbiology, 10(November), 1-13. https://doi.org/10. 3389/fmicb.2019.02548

Bubpachat, T., Sombatsompop, N., \& Prapagdee, B. (2018). Isolation and role of polylactic acid-degrading bacteria on degrading enzymes productions and PLA biodegradability at mesophilic conditions. Polymer Degradation and Stability, 152, 75-85. https://doi.org/10.1016/j. polymdegradstab.2018.03.023

Butbunchu, N., \& Pathom-Aree, W. (2019). Actinobacteria as promising candidate for polylactic acid type bioplastic degradation. Frontiers in Microbiology, 10(December). https://doi.org/10.3389/fmicb.2019.02834
Cavicchioli, R., Charlton, T., Ertan, H., Omar, S. M., Siddiqui, K. S., \& Williams, T. J. (2011). Biotechnological uses of enzymes from psychrophiles. Microbial Biotechnology, 4(4), 449-460. https://doi.org/10.1111/ j.1751-7915.2011.00258.x

Chaisu, K., Charles, A. L., Guu, Y., \& Chiu, C. (2012). Optimization of poly lactic acid (PLA) plastic degradation by Aneurinibacillus migulanus using Response Surface Methodology. International Proceedings of Chemical, Biological \& Environmenta, 40, 22-27.

Chinaglia, S., Tosin, M., \& Degli-Innocenti, F. (2018). Biodegradation rate of biodegradable plastics at molecular level. Polymer Degradation and Stability, 147(December 2017), 237-244. https://doi.org/10.1016/j. polymdegradstab.2017.12.011

Chomchoei, A., Pathom-Aree, W., Yokota, A., Kanongnuch, C., \& Lumyong, S. (2011). Amycolatopsis thailandensis sp. nov., a poly(L-lactic acid)-degrading actinomycete, isolated from soil. International Journal of Systematic and Evolutionary Microbiology, 61(4), 839-843. https://doi.org/10.1099/ ijs.0.023564-0

Çolak, A., Şişik, D., Saglam, N., Güner, S., Çanakçi, S., \& Beldüz, A. O. (2005). Characterization of a thermoalkalophilic esterase from a novel thermophilic bacterium, Anoxybacillus gonensis G2. Bioresource Technology, 96(5), 625-631. https://doi.org/10.1016/j. biortech.2004.06.003

D’Amico, S., Collins, T., Marx, J. C., Feller, G., \& Gerday, C. (2006). Psychrophilic microorganisms: Challenges for life. EMBO Reports, 7(4), 385-389. https://doi. org/10.1038/sj.embor.7400662

Dang, T. C. H., Nguyen, D. T., Thai, H., Nguyen, T. C., Hien Tran, T. T., Le, V. H., Nguyen, V. H., Tran, X. B., Thao Pham, T. P., Nguyen, T. G., \& Nguyen, Q. T. (2018). Plastic degradation by thermophilic Bacillus sp. BCBT21 isolated from composting 
agricultural residual in Vietnam. Advances in Natural Sciences: Nanoscience and Nanotechnology, 9(1). https://doi.org/10. 1088/2043-6254/aaabaf

Danso, D., Chow, J., \& Streita, W. R. (2019). Plastics: Environmental and biotechnological perspectives on microbial degradation. Applied and Environmental Microbiology, 85(19). https://doi. org/10.1128/AEM.01095-19

Decorosi, F., Exana, M. L., Pini, F., Adessi, A., Messini, A., Giovannetti, L., \& Viti, C. (2019). The degradative capabilities of new Amycolatopsis isolates on polylactic acid. Microorganisms, 7(12), 1-17. https://doi. org/10.3390/microorganisms7120590

Di Donato, P., Buono, A., Poli, A., Finore, I., Abbamondi, G. R., Nicolaus, B., \& Lama, L. (2018). Exploring marine environments for the identification of extremophiles and their enzymes for sustainable and green bioprocesses. Sustainability (Switzerland), 11(1). https://doi.org/10.3390/su11010149

Dussud, C., Hudec, C., George, M., Fabre, P., Higgs, P., Bruzaud, S., Delort, A. M., Eyheraguibel, B., Meistertzheim, A. L., Jacquin, J., Cheng, J., Callac, N., Odobel, C., Rabouille, S., \& Ghiglione, J. F. (2018). Colonization of non-biodegradable and biodegradable plastics by marine microorganisms. Frontiers in Microbiology, 9(JUL), 1-13. https://doi.org/10.3389/ fmicb.2018.01571

Elsawy, M. A., Kim, K. H., Park, J. W., \& Deep, A. (2017). Hydrolytic degradation of polylactic acid (PLA) and its composites. Renewable and Sustainable Energy Reviews, 79 (April), 1346-1352. https://doi. org/10.1016/j.rser.2017.05.143

Farah, S., Anderson, D. G., \& Langer, R. (2016). Physical and mechanical properties of PLA, and their functions in widespread applications - A comprehensive review. Advances Drug Delivery Review, 107, 367392. https://doi.org/10.1016/j.addr.2016.06. 012
Gan, Z., \& Zhang, H. (2019). PMBD: A comprehensive plastics microbial biodegradation database. Database: The Journal of Biological Databases and Curation, 1-11. https://doi.org/10.1093/ database/baz119

Hadad, D., Geresh, S., \& Sivan, A. (2005). Biodegradation of polyethylene by the thermophilic bacterium Brevibacillus borstelensis. Journal of Applied Microbiology, 98(5), 1093-1100. https:// doi.org/10.1111/j.1365-2672.2005.02553.x

Hajighasemi, M., Nocek, B. P., Tchigvintsev, A., Brown, G., Flick, R., Xu, X., Cui, H., Hai, T., Joachimiak, A., Golyshin, P. N., Savchenko, A., Edwards, E. A., \& Yakunin, A. F. (2016). Biochemical and structural insights into enzymatic depolymerization of polylactic acid and other polyesters by microbial carboxylesterases. Biomacromolecules, 17(6), 2027-2039. https://doi.org/10.1021/ acs.biomac.6b00223

Haki, G. D., \& Rakshit, S. K. (2003). Developments in industrially important thermostable enzymes: A review. Bioresource Technology, 89(1), 17-34. doi: 10.1016/s0960-8524(03)00033-6.

Hanphakphoom, S., Maneewong, N., Sukkhum, S., Tokuyama, S., \& Kitpreechavanich, V. (2014). Characterization of poly(Llactide)-degrading enzyme produced by thermophilic filamentous bacteria Laceyella sacchari LP175. Journal of General and Applied Microbiology, 60(1), 13-22. https:// doi.org/10.2323/jgam.60.13

Hedstrom, L. (2002). Serine protease mechanism and specificity. Chemical Reviews, 102, 4501-4524. https://doi.org/10.1021/cr0000 $33 \mathrm{x}$

Jiang, X., Chen, H, Liao, Y., Ye, Z., Li, M., \& Klobučar, G. (2019) Ecotoxicity and genotoxicity of polystyrene microplastics on higher plant Vicia faba. Environmental Pollution, 250, 831-838. https://doi. org/10.1016/j.envpol.2019.04.055 
Jem, K. J., \& Tan, B. (2020). The development and challenges of poly (lactic acid) and poly (glycolic acid). Advanced Industrial and Engineering Polymer Research, 3(2), 60-70. https://doi.org/10.1016/j.aiepr.2020.01.002

Kale, S. K., Deshmukh, A. G., Dudhare, M. S., \& Patil, V. B. (2015). Microbial degradation of plastic: A review. Journal of Biochemical Technology, 6(2), 952-961.

Kawai, F., Nakadai, K., Nishioka, E., Nakajima, H., Ohara, H., Masaki, K., \& Iefuji, H. (2011). Different enantioselectivity of two types of poly(lactic acid) depolymerases toward poly(l-lactic acid) and poly(d-lactic acid). Polymer Degradation and Stability, 96(7), 1342-1348. https://doi.org/10.1016/j. polymdegradstab.2011.03.022

Kim, M. Y., Kim, C., Moon, J., Heo, J., Jung, S. P., \& Kim, J. R. (2017). Polymer film-based screening and isolation of polylactic acid (PLA)-degrading microorganisms. Journal of Microbiology and Biotechnology, 27(2), 342-349. https://doi.org/10.4014/ jmb.1610.10015

Kirstein, I. V., Wichels, A., Gullans, E., Krohne, G., \& Gerdts, G. (2019). The plastisphere - Uncovering tightly attached plastic "specific" microorganisms. PLOS ONE, 14(4), 1-17. https://doi.org/10.1371/journal. pone. 0215859

Kubowicz, S., \& Booth, A. M. (2017). Biodegradability of plastics: Challenges and misconceptions. Environmental Science and Technology, 51(21), 12058-12060. https://doi.org/10.1021/acs.est.7b04051

Lahive, E., Walton. A., Horton, A. A., Spurgeon, D. J., \& Svendsen, C. (2019). Microplastic particles reduce reproduction in the terrestrial worm Enchytraeus crypticus in a soil exposure. Environmental Pollution, 225, 113174. https://doi.org/10.1016/j. envpol.2019.113174

Lenz, R. W. (1993) Biodegradable polymers. In R. S. Langer, N. A. Peppas (Eds.),
Biopolymers I, 107, 1-40. Berlin Heidelberg: Springer.

Li, S. M., \&Vert, M. (1994). Morphological changes resulting from the hydrolytic degradation of stereo-copolymers derived from L- and DL-lactides. Macromolecules, 27(11), 3107-3110. https://doi.org: 10.1021/ ma00089a031, 3107-3110.

Li, F., Wang, S., Liu, W., \& Chen, G. (2008). Purification and characterization of poly(1lactic acid)-degrading enzymes from Amycolatopsis orientalis ssp. orientalis. FEMS Microbiology Letters, 282(1), 52-58. https://doi.org/10.1111/j.15746968.2008.01109.x

Liang, T. W., Jen, S. N., Nguyen, A. D., \& Wang, S. L. (2016). Application of chitinous materials in production and purification of a poly(L-lactic acid) depolymerase from Pseudomonas tamsuii TKU015. Polymers, $8(3), \quad 1-11$. https://doi.org/10.3390/ polym 8030098

Lim, H. A., Raku, T., \& Tokiwa, Y. (2005). Hydrolysis of polyesters by serine proteases. Biotechnology Letters, 27(7), 459-464. https://doi.org/10.1007/s10529-005-2217-8

Lucas, N., Bienaime, C., Belloy, C., Queneudec, M., Silvestre, F., \& Nava-Saucedo, J. E. (2008). Polymer biodegradation: Mechanisms and estimation techniques - A review. Chemosphere, 73(4), 429-442. https://doi.org/10.1016/j. chemosphere.2008.06.064

Margesin, R., \& Schinner, F. (2001). Biodegradation and bioremediation of hydrocarbons in extreme environments. Applied Microbiology and Biotechnology, 56(5-6), 650-663. https://doi.org/10.1007/ s002530100701

Margesin, R., \& Feller, G. (2010). Biotechnological applications of psychrophiles. Environmental Technology, 31(8-9), 835-844. https://doi.org/10.1080/ 09593331003663328 
Matsuda, E., Abe, N., Tamakawa, H., Kaneko, J., \& Kamio, Y. (2005). Gene cloning and molecular characterization of an extracellular poly(L-lactic acid) depolymerase from Amycolatopsis sp. strain K104-1. Journal of Bacteriology, 187(21), 7333-7340. https://doi.org/10.1128/JB.187. 21.7333-7340.2005

Michaud, L., Di Marco, G., Bruni, V., \& Lo Giudice, A. (2007). Biodegradative potential and characterization of psychrotolerant polychlorinated biphenyldegrading marine bacteria isolated from a coastal station in the Terra Nova Bay (Ross Sea, Antarctica). Marine Pollution Bulletin, 54(11), 1754-1761. https://doi. org/10.1016/j.marpolbul.2007.07.011

Moharir, R. V., \& Kumar, S. (2019). Challenges associated with plastic waste disposal and allied microbial routes for its effective degradation: A comprehensive review. Journal of Cleaner Production, 208, 65-76. https://doi.org/10.1016/j. jclepro.2018.10.059

Mohee, R., Unmar, G. D., Mudhoo, A., \& Khadoo, P. (2008). Biodegradability of biodegradable/degradable plastic materials under aerobic and anaerobic conditions. Waste Management, 28(9), 1624-1629. https://doi.org/10.1016/j.wasman. 2007.07.003

Morita, R. Y. (1975). Psychrophilic bacteria. Bacteriological Reviews, 39(2), 144-167. https://doi.org/10.1128/mmbr.39.2.144167.1975

Moyer, C. L., \& Morita, R. Y. (2007). Psychrophiles and psychrotrophs. Encyclopedia of Life Sciences, 1-6. https://doi.org/10.1002/9780470015902. a0000402.pub2

Mueller, R. J. (2006). Biological degradation of synthetic polyesters-enzymes as potential catalysts for polyester recycling. Process Biochemistry, 41(10), 2124-2128. https:// doi.org/10.1016/j.procbio.2006.05.018
Muhonja, C. N., Makonde, H., Magoma, G., \& Imbuga, M. (2018). Biodegradability of polyethylene by bacteria and fungi from Dandora dumpsite Nairobi-Kenya. PLoS ONE, 13(7), 1-17. https://doi.org/10.1371/ journal.pone.0198446

Nakamura, K., Tomita, T., Abe, N., \& Kamio, Y. (2001). Purification and characterization of an extracellular poly(L-lactic acid) depolymerase from a soil isolate, Amycolatopsis sp. strain K104-1. Applied and Environmental Microbiology, 67(1), 345-353. https://doi.org/10.1128/ AEM.67.1.345-353.2001

Nakayama, A., Yamano, N., \& Kawasaki, N. (2019). Biodegradation in seawater of aliphatic polyesters. Polymer Degradation and Stability, 166, 290-299. https:// doi.org/10.1016/j.polymdegradstab. 2019.06.006

Noor, H., Satti, S. M., Din, S. ud, Farman, M., Hasan, F., Khan, S., Badshah, M., \& Shah, A. A. (2020). Insight on esterase from Pseudomonas aeruginosa strain S3 that depolymerize poly(lactic acid) (PLA) at ambient temperature. Polymer Degradation and Stability, 174, 109096. https://doi.org/10.1016/j. polymdegradstab.2020.109096

Palmisano, A. C., \& Pettigrew, C. A. (1992) Biodegradability of plastics, BioScience, 42(9), 680-685, https://doi.org/10.2307/ 1312174

Panyachanakul, T., Sorachart, B., Lumyong, S., Lorliam, W., Kitpreechavanich, V., \& Krajangsang, S. (2019). Development of biodegradation process for Poly(DL-lactic acid)degradation by crude enzyme produced by Actinomadura keratinilytica strain T161. Electronic Journal of Biotechnology, 40, 52-57. https://doi.org/10.1016/j.ejbt. 2019.04.005

Pattanasuttichonlakul, W., Sombatsompop, N., \& Prapagdee, B. (2018). Accelerating biodegradation of PLA using microbial consortium from dairy wastewater sludge 
combined with PLA-degrading bacterium. International Biodeterioration and Biodegradation, 132(May), 74-83. https:// doi.org/10.1016/j.ibiod.2018.05.014

Prema, S., \& Devi, U. M. (2014). Degradation of Polylactide Film by Depolymerase from Bacillus amyloliquefaciens. International Journal of Scientific \& Engineering Research, 5(11), 520-525.

Prema, S., Maheswari, U., \& Palempalli, D. (2015). Degradation of Polylactide Plastic by PLA Depolymerase isolated from Thermophilic Bacillus. International Journal of Current Microbiology and Applied Sciences, 4(12), 645-654. http:// www.ijcmas.com

Ribitsch, D., Acero, E. H., Greimel, K., Dellacher, A., Zitzenbacher, S., Marold, A., Rodriguez, R. D., Steinkellner, G., Gruber, K., Schwab, H., \& Guebitz, G. M. (2012). A new esterase from Thermobifida halotolerans hydrolyses polyethylene terephthalate (PET) and polylactic acid (PLA). Polymers, 4(1), 617-629. https:// doi.org/10.3390/polym4010617

Ruggero, F., Gori, R., \& Lubello, C. (2019). Methodologies to assess biodegradation of bioplastics during aerobic composting and anaerobic digestion: A review. Waste Management and Research, 37(10), 959-975. https://doi. org/10.1177/0734242X19854127

Sakai, K., Kawano, H., Iwami, A., Nakamura, M., \& Moriguchi, M. (2001). Isolation of a thermophilic poly-L-lactide degrading bacterium from compost and its enzymatic characterization. Journal of Bioscience and Bioengineering, 92(3), 298-300. https://doi. org/10.1016/S1389-1723(01)80266-8

Satti, S. M., Shah, A. A., Auras, R., \& Marsh, T. L. (2017). Isolation and characterization of bacteria capable of degrading poly(lactic acid) at ambient temperature. Polymer Degradation and Stability, 144, 392-400. https://doi.org/10.1016/j. polymdegradstab.2017.08.023
Sekiguchi, T., Sato, T., Enoki, M., Kanehiro, H., Uematsu, K., \& Kato, C. (2010). Isolation and characterization of biodegradable plastic degrading bacteria from deep-sea environment. JAMSTEC Report of Research and Development, 11, 33-41. https://doi. org/10.5918/jamstecr.11.33

Shah, A. A., Nawaz, A., Kanwal, L., Hasan, F., Khan, S., \& Badshah, M. (2015). Degradation of poly( $\varepsilon$-caprolactone) by a thermophilic bacterium Ralstonia sp. strain MRL-TL isolated from hot spring. International Biodeterioration and Biodegradation, 98, 35-42. https://doi. org/10.1016/j.ibiod.2014.11.017

Shi, K., Jing, J., Song, L., Su, T., \& Wang, Z. (2020). Enzymatic hydrolysis of polyester: Degradation of poly( $\varepsilon$-caprolactone) by Candida antarctica lipase and Fusarium solani cutinase. International Journal of Biological Macromolecules, 144, 183189. https://doi.org/10.1016/j.ijbiomac. 2019.12.105

Sivan, A. (2011). New perspectives in plastic biodegradation. Current Opinion in Biotechnology, 22(3), 422-426. https://doi. org/10.1016/j.copbio.2011.01.013

Sukkhum, S., Tokuyama, S., Tamura, T., \& Kitpreechavanich, V. (2009). A novel poly (L-lactide) degrading actinomycetes isolated from Thai forest soil, phylogenic relationship and the enzyme characterization. Journal of General and Applied Microbiology, 55(6), 459-467. https://doi.org/10.2323/jgam.55.459

Sun, X., Chen, B., Li, Q., Liu, N., Xia, B., Zhu, L., \& Qu, K. (2018). Toxicities of polystyrene nano- and microplastics toward marine bacterium Halomonas alkaliphila. Science of the Total Environment, 642, 1378-1385. https://doi.org/10.1016/j.scito tenv.2018.06.141

Teeraphatpornchai, T., Nakajima-Kambe, T., Shigeno-Akutsu, Y., Nakayama, M., Nomura, N., Nakahara, T., \& Uchiyama, H. (2003). Isolation and characterization 
of a bacterium that degrades various polyester-based biodegradable plastics. Biotechnology Letters, 25(1), 23-28. https:// doi.org/10.1023/A:1021713711160

Tokiwa, Y., \& Calabia, B. P. (2004). Degradation of microbial polyesters. Biotechnology Letters, 26(15), 1181-1189. https://doi. org/10.1023/B:BILE.0000036599.15302. e5

Tomita, K., Tsuji, H., Nakajima, T., Kikuchi, Y., Ikarashi, K., \& Ikeda, N. (2003). Degradation of poly(D-lactic acid) by a thermophile. Polymer Degradation and Stability, 81(1), 167-171. https://doi. org/10.1016/S0141-3910(03)00086-7

Tomita, K., Nakajima, T., Kikuchi, Y., \& Miwa, N. (2004). Degradation of poly(L-lactic acid) by a newly isolated thermophile. Polymer Degradation and Stability, 84(3), 433-438. https://doi.org/10.1016/j. polymdegradstab.2003.12.006

Urbanek, A. K., Mirończuk, A. M., GarcíaMartín, A., Saborido, A., de la Mata, I., \& Arroyo, M. (2020). Biochemical properties and biotechnological applications of microbial enzymes involved in the degradation of polyester-type plastics. Biochimica et Biophysica Acta - Proteins and Proteomics, 1868(2), 140315. https:// doi.org/10.1016/j.bbapap.2019.140315

Urbanek, A. K., Rymowicz, W., Strzelecki, M. C., Kociuba, W., Franczak, Ł., \& Mirończuk, A. M. (2017). Isolation and characterization of Arctic microorganisms decomposing bioplastics. AMB Express, 7(1). https://doi.org/10.1186/s13568-0170448-4

Vieille, C., \& Zeikus, G. J. (2001). Hyperthermophilic Enzymes. Microbiology and Molecular Biology Reviews, 65(1), 1-43. https://doi.org/10.1128/MMBR.65.1.1

Wang, Z., Wang., Y., Guo, Z., Li, F., \& Chen, S. (2011). Purification and characterization of poly (L-lactic acid) depolymerase from Pseudomonas sp. strain DS04-T. Polymer Engineering and Science, 51(3), 454-459. https://doi.org/10.1002/pen.21857

Webb, H. K., Arnott, J., Crawford, R. J., \& Ivanova, E. P. (2013). Plastic degradation and its environmental implications with special reference to poly(ethylene terephthalate). Polymers, 5(1), 1-18. https:// doi.org/10.3390/polym5010001

Williams., D. F. (1981). Enzymatic hydrolysis of polylactic acid. Engineering in Medicine 10(1), 5-7. https://doi.org/10.1243/EMED_ JOUR_1981_010_004_02

Yang, H-S., Yoon, J-S., \& Kim, M-N. (2005). Dependence of biodegradability of plastics in compost on the shape of specimens. Polymer Degradation and Stability, 87(1), 131-135. https://doi.org/10.1016/j. polymdegradstab.2004.07.016

Yagi, H., Ninomiya, F., Funabashi, M., \& Kunioka, M. (2014). Mesophilic anaerobic biodegradation test and analysis of eubacteria and archaea involved in anaerobic biodegradation of four specified biodegradable polyesters. Polymer Degradation and Stability, 110, 278-283. https://doi.org/10.1016/j. polymdegradstab.2014.08.031

Zheng, Y., Yanful, E. K., \& Bassi, A. S. (2005). A review of plastic waste biodegradation. Critical Reviews in Biotechnology, 25(4), 243-250. https:// doi:10.1080/07388550500346359 